\title{
CTNNA2 Gene
}

National Cancer Institute

\section{Source}

National Cancer Institute. CTNNA2 Gene. NCI Thesaurus. Code C143115.

This gene is involved in cell-cell adhesion and cellular differentiation in the nervous system. 